\title{
PLURALISME AGAMA DI INDONESIA (Tantangan dan Peluang Bagi Keutuhan Bangsa)
}

\author{
Julita Lestari \\ julitalestari3007@gmail.com \\ Universitas Islam Negeri Sunan Kalijaga Yogyakarta
}

DOI: $10.21580 /$ wa.v6i1.4913

\begin{abstract}
Religious diversity on the one hand makes a difference that tends to give birth to divisions among religious communities. On the other hand, religious diversity is a unifying people because they respect each other's differences. Pluralism which gives birth to two sides makes it important to study. Indonesia is one country that adheres to not only one religion but consists of various religions, namely Islam, Christianity, Buddhism, Confucianism, Hindu and other religions. Religious pluralism in Indonesia has its own challenges and opportunities for national integrity. Indonesia's biggest challenge as a state of pluralism is that it tends to cause conflict. Because every religion makes truth claims against its own religion and other religions are considered wrong. The opportunity for religious pluralism in Indonesia for the integrity of the nation is the birth of a tolerant attitude among people because it is able to appreciate religious diversity.
\end{abstract}

Keywords: Religious Pluralism, challenges, opportunities, Indonesia

\begin{abstract}
Abstrak
Keberagaman agama di satu sisi menjadikan perbedaan yang cenderung melahirkan perpecahan di kalangan umat beragama. Di sisi lain, keberagaman agama merupakan pemersatu umat karena saling menghargai perbedaan yang ada. Pluralisme yang melahirkan dua sisi ini menjadikan penting untuk dikaji. Indonesia merupakan salah satu negara yang menganut tidak hanya satu agama namun terdiri bermacam-macam agama, yaitu Islam, Kristen, Budha, Kong $\mathrm{Hu}$ chu, Hindudan agama-agama lainnya. Kepluralismean agama di Indonesia ini memiliki tantangan dan peluang tersendiri bagi keutuhan bangsa. Tantangan terbesar Indonesia sebagai negara pluralisme adalah cenderung menimbulkan konflik. Dikarenakan setiap agama melakukan truth claim terhadap agamanya sendiri dan agama lain dianggap salah. Adapun peluang pluralisme agama di Indonesia bagi keutuhan bangsa yaitu
\end{abstract}


lahirnya sikap toleran sesama umat karena mampu menghargai keragaman beragama.

\section{Kata Kunci: Pluralisme Agama, tantangan, peluang, Indonesia}

\section{A. Pendahuluan}

Bangsa lndonesia adalah bangsa yang majemuk. Salah satu sisi kemajemukan bangsa Indonesia adalah adanya keragaman agama yang dipeluk dan kepercayaan yang diyakini oleh penduduknya. Dengan kata lain agama dan kepercayaan yang hidup dan berkembang di Indonesia tidaklah tunggal namun beragam. Ada agama-agama besar seperti Islam, Kristen Katolik, Protestan,Hindu, Buddha, Konghucu, bahkan Yahudi. Kenyataan sosial keagamaan yang demikian sebenarnya telah dipahami para pendiri bangsa: bahwa beragama merupakan hak setiap penduduk dan hak ini harus dijamin oleh Negara. Karena itulah mengapa dalam undang-Undang Dasar 1945 terdapat Pasal 29 ayat (1) dan ayat (2) yang menyatakan bahwa, "Negara berdasar atas Ketuhanan Yang Maha Esa," Negara menjamin kemerdekaan tiap-tiap penduduk untuk memeluk agamanya masing-masing dan untuk beribadat menurut agama dan kepercayaannya itu. ${ }^{1}$

Baik Pancasila maupun UUD 1945 sesungguhnya merupakan jaminan bagi eksistensi agama dan kepercayaan di Indonesia. Jaminan akan eksistensi agama dan kepercayaan berarti bahwa setiap agama dan kepercayaan yang ada dan hidup di Indonesia mestilah dijamin oleh Negara untuk menjalankan ajaran agama dan ajaran kepercayaan serta beribadat menurut agama dan kepercayaan yang diyakininya. ${ }^{2}$

Agama dan masyarakat secara kesatuan mempunyai jalinan yang erat dan saling mempengaruhi satu sama lainnya. Dalam agama terkandung sumber nilai dan moral universal sehingga dapat membentuk sikap dan prilaku manusia dalam menjawab tantangan kehidupan. Bahkan dikatakan manusia sebagai makhluk sosial belum menjadi manusia sepenuhnya tanpa agama. Dalam sebuah dialog antara teolog bernama Leonardo Boff dan Dalai Lama menjelaskan bahwa "yang membuat seseorang menjadi baik, lebih sabar, peduli antar sesama, memiliki rasa kemanusiaan, bertanggung jawab, dan beretika, maka agamanya telah bekerja", dalam dialog mengajarkan bahwa betapa agama dapat menjadi amat fungsional dan bekerja dengan baik, ketika agama dapat merefleksi pada perilaku keseharian seseorang menjadi pribadi yang baik. Agama bukan nilai yang terpisah dari kehidupan nyata, tetapi menyatu dalam perilaku manusia. ${ }^{3}$

Agama merupakan aturan hidup manusia yang memberikan pengajaran serta nilainilai kebaikan yang harus dikerjakan setiap pemeluknya. Adapun dalam bahasa Schimmel, yang dikutip dari Andito agama sebagai dimensi kohesi dan konsensus yaitu suatu

${ }^{1}$ Iskandar Zulkarnain, "Hubungan Antar komunitas Agama Di Indonesia : Masalah Dan Penanganannya”, Vol 16 No.4 Desember 2011, hlm. 682-683

2Iskandar Zulkarnain, "Hubungan Antar komunitas”..., hlm. 683

${ }^{3}$ Catur Widiat Moko, "Pluralisme Agama Menurut Nurcholis Madjid (1939-2005) Dalam Konteks Keindonesiaan”, Medina-Te, Vol.16, No.1, Juni 2017, hlm. 62 
hubungan yang membangun komunikasi dalam nilai-nilai hukum yang ada dalam kontruksi setiap agama, agama dapat ditafsirkan dalam peran ganda (Double Standard). Artinya, agama sebagai penyebab konflik sekaligus dapat menjadi faktor peredam konflik. ${ }^{4}$

\section{B. Teori yang digunakan}

Nurcholis Madjid diistilahkan menjadi "desa buana” (global village), dimana manusia bebas dan mudah berhubungan dengan manusia yang lain, baik secara etnis, budaya, bahasa, dan agama. Dalam kondisi semacam ini, manusia akan semakin intim dan mendalam dalam mengenal dan memahami orang lain, sekaligus akan lebih mudah terbawa pada penghayatan konfrontasi langsung. Adanya dunia "tanpa jarak" ini, menuntut sikap kritis dan apresiasif dengan mengedepankan sikap yang memandang bahwa semua itu adalah bagian dari keniscayaan hidup yang harus dihargai sebagaimana mestinya. Sehingga dapat hidup menjadi bagian dari masyarakat dunia. ${ }^{5}$

\section{Pembahasan dan hasil}

\section{Kehidupan Beragama di Indonesia}

Fenomena kehidupan beragama memiliki daya tarik tersendiri sekaligus menyedot perhatian cukup besar dari semua kalangan. Baragam kasus telah kita lihat mulai dari betapa mudahnya mensesatkan antara satu faham keagamaan dengan faham keagamaan lainnya, penistaan agama dan nikah beda agama. Jika semua orang meyakini agama sebagai pedoman hidupnya, maka akan meyakini pula bahwa agama bernilai universal, dinamis, fleksibel, dan berorientasi ke depan. Agama apa pun tidak memiliki makna apa-apa jika tidak diikuti, diakui, dan diyakini sebagai kebenaran mutlak dan menjadi pedoman hidup bagi para penganutnya. Di sinilah dapat diketahui dinamika kehidupan beragama bergantung kepada para penganutnya. ${ }^{6}$

Tata cara pengamalan ajaran oleh masing-masing pemeluk agama dengan penuh kesadaran bahwa tidak saling membenarkan agama yang dianutnya. Karena setiap agama memiliki ajaran-ajaran yang khas, yang mencirikan dan sekaligus membedakannya dengan yang lain. Tidak mengaktifkan simbol-simbol agama atau tidak menonjolkan identitas agama dalam interaksi secara penuh merupakan pengakuan akan adanya perbedaanperbedaan diantara agama-agama tersebut dan sekaligus menghargai perbedaan- perbedaan itu. Dengan begitu interaksi antar umat beragama menjadi bagian yang saling menguntungkan timbal-balik antar umat beragamapun terjadi dengan wujud kerukunan atau toleransi antar umat beragama. Dalam mewujudkan kebaikan, hampir setiap agama

${ }^{4}$ Catur Widiat Moko, "Pluralisme Agama Menurut Nurcholis Madjid"..., hlm. 62

${ }^{5}$ Said Masykur, "Pluralisme Dalam Konteks Studi Agama-Agama", Toleransi: Media Komunikasi Umat Beragama Vol. 8, No. 1, Januari - Juni 2016, hlm. 65-66

${ }^{6}$ Adeng Muchtar Ghazali, "Pendidikan Islam dalam Dinamika Kehidupan Beragama di Indonesia", Intizar, Volume 23, No. 1, 2017, hlm. 93-94 
menggariskan dua pola hubungan yang harus dilaksanakan oleh pemeluknya, yaitu hubungan yang bersifat vertikal dan hubungan yang bersifat horizontal. Hubungan yang bersifat vertikal menciptakan suatu hubungan manusia dengan penciptanya direalisasikan dengan ibadah setiap harinya sebagaimana yang telah digariskan oleh setiap agama. Pada hubungan ini, berupa toleransi antar umat beragama yang merupakan unsur inti dari kerukunan umat beragama yang terbatas dalam lingkungan intern suatu agama. Sedangkan hubungan horizontal, atau pola hubungan manusia dengan sesamanya maupun manusia dengan masyarakat sekitar yang berlainan kebudayaan, ras, agama baik itu berupa kerjasama dalam bentuk kemasyarakatan ataupun pola individu dengan individu untuk menjalin rasa persaudaraan yang lebih erat. ${ }^{7}$

Dalam Negara Indonesia manusia membentuk dan menentukan corak masyarakat yang dikehendaki agar bentuk dan corak yang baik dapat terwujud, keberagaman dalam kehidupan beragama diindonesia perlu dipelihara, karena merupakan kenyataan yang telah ditetapkan oleh pemilik alam semesta ini, bila ada yang menolak, ia akan menemui kesulitan, karena berhadapan dengan kenyataan itu sendiri. ${ }^{8}$

Mengingat keberagaman (heterogenitas) merupakan realita dan dan ketentuan dari allah tuhan semesta alam maka bagi manusia tak ada alternatif lain, kecuali menerima dan memelihara dengan mengarahkan kepada kepentingan dan tujuan bersama, memang apabila tidak dipelihara dengan baik dapat saling bergesekkan sehingga terjadi perpecahan, dan tidak mustahil kepada separatisme. Tetapi karena bangsa Indonesia adalah bangsa yang religius dan menyadari bahwa keberagaman diindonesia ini merupakan ketentuan dan takdir allah yang mengtur alam, maka insan Indonesia menggalang dan membina persatuan bangsanya, bukan hanya itu dari keberagaman itu pulalah dihimpun hasrat-hasrat yang ada menjadi kolektif dan membangun memelihara kesatuan dan keutuhan bangsa dan Negara. Walaupun agama bersifat universal, namun dengan beragama tidak mengurangi rasa kebangsaan, bahkan menguat rasa kebangsaan. Karena agama mendorong penganutnya untuk membela kehormatan dan kedaulatan bangsa dan Negara.?

\section{Konsep Pluralisme}

Pluralisme berasal dari kata "plural” yang berarti banyak atau lebih dari satu. Kata plural sendiri berakar dari kata latin plus, pluris, yang secara bahasa berarti lebih dari satu. Sedangkan isme bisa diartikan dengan sesuatu yang berhubungan dengan aliran atau paham. Dengan demikian, pluralisme secara etimologi bisa dikatakan sebagai paham atau ajaran yang mengacu kepada adanya realitas atau kenyataan yang lebih dari satu substansi. ${ }^{10}$

${ }^{7}$ Yudwy Pradipta, ddk, "Efektifitas Komunikasi Interpersonal Umat Beragama di Perumahan Bekasi Jaya Indah Rt 10/14”, Studi Al-Quran, Volume. 10, No. 2, 2014, hlm. 112

${ }^{8}$ Toto Suryana, "Konsep Aktualisasi Kerukunan Antar Umat Beragama", Ta’lim, Vol. 9 No. 2 2011, hlm. 134

${ }^{9}$ Toto Suryana, “Konsep Aktualisasi Kerukunan”..., hlm. 134

${ }^{10}$ Fathur Rohman, Dkk, "Membangun Kerukunan Umat Beragama Dengan Nilai-Nilai Pluralisme Gus Dur”, An-Nuha Vol. 5, No. 2, Desember 2018, hlm. 158 
Pluralisme tidak bisa dipisahkan dengan makna pluralitas. Pluralitas adalah perbedaan dalam persoalan agama, etnik, budaya atau lainnya, sedangkan pluralisme adalah sistem nilai, sikap, dan proses yang bisa menerjemahkan realitas keragaman itu menjadi kohesi sosial yang berkelanjutan. Dengan kata lain, keragaman adalah sesuatu yang empiris, sementara pluralisme adalah ideologi atau paham yang menerima keragaman itu sebagai nilai positif dengan dibarengi upaya-upaya negosiasi dan penyesuaian di antara mereka, tanpa berusaha memusnahkan salah satu atau sebagian dari keragaman itu. Adanya perbedaan dalam agama misalnya, adalah kenyataan setiap masyarakat, dan pluralisme adalah orientasi yang mengasumsikan adanya penerimaan dan hubungan yang tulus atas fakta tersebut, bukannya malah memusnahkan atau melebur perbedaan itu menjadi satu. ${ }^{11}$

Pluralisme dapat kita jumpai dimana-mana. Didalam masyarakat tertentu dikantor ditempat bekerja, di sekolah tempat belajar, bahkan di pasar tempat belanja. Tapi seseorang baru dapat dikatakan menyandang sifat tersebut apabila ia dapat berintraksi positif didalam lingkungan kemajemukan tersebut. dengan kata lain. Pengertian pluralisme agama adalah bahwa tiap pemeluk agama dituntut bukan saja mengakui keberadan dan hak agama lain, tetapi terlibat dalam usaha memahami perbedaan dan persamaan guna tercapainya kerukunan dalam ke bhinekaan. ${ }^{12}$

Abdurrahman Wahid menekankan pentingnya keterbukaan untuk menemukan kebenaran di manapun. Menurutnya, berbagai peristiwa kerusuhan yang berkedok agama di beberapa tempat adalah akibat adanya eklusivisme agama. Menurut M. Amin Abdullah, keanekaragaman agama yang hidup di Indonesia, termasuk di dalamnya keanekaragaman paham keagamaan adalah merupakan kenyataan historis yang tidak dapat disangkal oleh siapapun. Menurut Abdullah, semua agama berbeda. Tidak ada agama yang sama. Berbeda dalam doktrin, institusi, kelembagaan, pemimpin, jenis umat, hari besar, ruang, tempat, waktu yang dianggap suci oleh pengikutnya, dan demikian seterusnya. Tetapi di dalam perbedaan itu terdapat commonalities, common pattern yang tidak dapat terekspresikan keluar. Artinya dalam masing-masing agama ada unsur-unsur yang memiliki kesamaan, seperti dimensi humanitas, rasa kemanusiaan, keadilan, keprihatinan terhadap lingkungan yang buruk, menolong orang-orang yang terpinggirkan, seperti orang miskin, perempuan, anak-anak, dan orang tua. Unsur-unsur kesamaan tersebut bukanlah hal yang relatif, tetapi justru absolut, yakni absolut dalam ide dasarnya, tetapi relatif dalam pelaksanaan dan implementasinya. ${ }^{13}$

Pendeknya pluralisme merupakan basis kerukunan yang dinamis dan dialogis dalam masyarakat majemuk, baik menyangkut perbedaan, seperti ras dan etnis maupun perbedaan perolehan, seperti pengetahuan, gagasan dan sebagainya. Dalam pada itu, agama oleh Osman ditempatkan pada ruang antara perbedaan bawaan dan perolehan. Sebab agama

\footnotetext{
${ }^{11}$ Fathur Rohman, Dkk,"Membangun Kerukunan Umat Beragama"..., hlm.159

${ }^{12}$ Imam Subkhan, Hiruk Pikuk Wacana Pluralisme di Yogya, (Yogyakarta: Kanisius, 2007), hlm. 29

${ }^{13}$ Umi Sumbulah, dkk, Pluralisme Agama: Makna dan Lokalitas Pola Kerukunan Antar umat Beragama, (Malang: Maliki Press, 2013), hlm. 34
} 
boleh jadi merupakan warisan dari orang tua atau sebagai perolehan yang didapat dari suatu sistem kepercayaan melalui keyakinan pribadi. Kalau perbedaan-perbedaan itu dapat ditata dengan baik diatas pluralisme, roda kehidupan sosial akan berjalan lancer, konsep pluralisme yang demikian menurut Alwi Shihab, pada garis besar dapat disimpulkan sebagai berikut: pertama, pluralisme bukan hanya beragam atau majemuk, pluralisme lebih dari sekedar majemuk atau beragam dengan keterlibatan aktif terhadap kemajemukan itu. Kedua, pluralisme harus dibedakan dengan kosmopolitanisme. Kosmopolitanisme menunjuk kepada suatu realitas dimana aneka agama, ras, bangsa hidup berdampingan pada suatu lokasi, kendati tanpa interaksi positif. Ketiga, konsep pluralisme tidak sama dengan relativisme. Relativisme berasumsi bahwa kebenaran atau nilai ditentukan oleh pandangan hidup serta kerangka berfikir seseorang atau masyarakat, sehingga aliran ini mengenal kebenaran universal. Keempat, pluralisme agama bukan sinkretisme, yakni agama baru yang diracik dari ajaran agama-agama yang telah mapan secara persial. ${ }^{14}$

\section{Pluralisme Agama di Indonesia}

Ketika kata pluralisme ini disandingkan dengan agama, maka makna pluralisme berubah menjadi sebuah istilah yang disebut pluralisme agama (religious pluralism). Istilah pluralisme agama telah menjadi terminologi khusus yang sudah baku (technical term). Untuk itu, ia tidak bisa hanya sekadar dirujuk ke dalam kamus-kamus bahasa. Walaupun dalam kamus terdapat makna pluralisme sebagai toleransi atau sikap saling menghormati keunikan masing-masing, tetapi pluralisme agama adalah sebuah paham atau cara pandang terhadap pluralitas agama yang paham ini memandang semua agama adalah sama atau setara dengan agama-agama lainnya. ${ }^{15}$

Pluralisme agama di Indonesia saling tarik menarik sehingga menimbulkan masalah antara teologi, sejarah dan primodialisme, pluralisme ketika berhadapan dengan masalah teologi dalam lingkungan intern umat beragama sendiri, baik Katolik, Protestan, Islam, Hindu, Budha, Konghucu dan agama-agama lain, masih disibukan oleh persoalan truth claim (klaim kebenaran) dengan melupakan aspek esoteris agama-agama yang ada. Masalah sejarah, secara historis, penjajahan Belanda sering kali menjadi beban sejarah yang mewarnai hubungan ini, karena Belanda selalu diidentikkan dengan Kristen, dan dalam setiap kebijakan politiknya selalu berpihak pada agama Kristen. Masalah lain dalam melihat pluralisme di Indonesia adalah primodialisme, juga dianggap sebagai faktor pengganjal dalam memahami persoalan kebenaran universal, termasuk menghambat perkembangan pemikiran keagamaan. ${ }^{16}$

${ }^{14}$ Yunasril Ali, Sufisme Dan Pluralisme: Memahami Hakikat Agama-Agama Dan Relasi Agama-Agama, (Jakarta: PT Alex Media Komputindo, 2012), hlm. 72

${ }^{15}$ Ahmad Khaerurrozikin, "Problem Sosiologis Pluralisme Agama Di Indonesia", KALIMAH, Vol. 13, No. 1, Maret 2015, hlm. 88

${ }^{16}$ Marsudi Utoyo, "Wewenang Dan Tugas Pemerintah Dalam Perkembangan Paham Pluralisme Agama”, Lex Librum, Vol. II, No. 1, Desenfier 2015, hlm. 200 
Pluralisme agama sendiri dimaknai secara berbeda-beda di kalangan cendekiawan Muslim Indonesia, baik secara sosiologis, teologis maupun etis. Secara sosiologis, pluralisme agama adalah suatu kenyataan bahwa kita adalah berbeda-beda, beragam dan plural dalam hal beragama. Ini adalah kenyataan sosial, sesuatu yang niscaya dan tidak dapat dipungkiri lagi. Dalam kenyataan sosial, kita telah memeluk agama yang berbeda-beda. Pengakuan terhadap adanya pluralisme agama secara sosiologis ini merupakan pluralisme yang paling sederhana, karena pengakuan ini tidak berarti mengizinkan pengakuan terhadap kebenaran teologi atau bahkan etika dari agama lain. ${ }^{17}$

Pluralisme agama juga merupakan fenomena yang tidak bisa dihindari adanya. Jika pluralisme agama tidak disikapi secara cermat dan tepat, bisa jadi akan menimbulkan problem dan konflik antar umat beragama. Tampaknya kenyataan ini telah terjadi pada agama-agama. Untuk mencari solusi adanya konflik antar umat beragama perlu adanya pendekatan-pendekatan yang tepat, di antaranya dengan menjalin hubungan antar umat beragama dengan baik. ${ }^{18}$

\section{Tantangan dan Peluang Pluralisme Agama di Indonesia}

\section{a. Tantangan}

Kenyataan memprihatinkan di tengah masyarakat dapat terbaca, bahwa belum semua pemeluk agama sadar dan bersikap “cerdas", menjunjung tinggi hak demokratisasi dan humanitas. Masih ada komunitas beragama yang terseret pada sikap eksklusif, mengutamakan klaim kebenaran (truth claims), arogansi etnis dan utamanya keserakahan kekuasaan, dendam dan friksi-friksi politik yang dibenarkan melalui pola manipulasi doktrin agama. ${ }^{19}$

Pluralisme merupakan tantangan bagi agama-agama, sehingga menjadi penting artinya dilakukan pencarian titik temu agama-agama. Ada beberapa pertimbangan sebagai kerangka acuan akan arti pentingnya pencarian konvergensi agama-agama. Pertama, secara praktis pluralisme agama belum sepenuhnya dipahami oleh umat beragama, sehingga yang tampil ke permukaan justru sikap eksklusivisme beragama, yang merasa ajarannya paling benar hanyalah ajaran agama yang dipeluknya. Agamaagama lain dituduh sesat, sehingga wajib dikikis atau pemeluknya ditobatkan, karena baik agama maupun pemeluknya terkutuk dalam pandangan Tuhan. Di sinilah akar konflik dimulai. Realitas ini merupakan bagian dari keberlanjutan konflik yang disebabkan oleh pola hubungan sosial lintas agama yang eksklusif. Pluralimse agama memang belum sepenuhnya menjamin kerukunan hidup beragama. Kedua, di tengahtengah pluralisme agama ini, hanyalah pemeluk agama tertentu (yang bersikap

\footnotetext{
${ }^{17}$ Umi Hanik, "Pluralisme Agama Di Indonesia", Volume 25 Nomor. 1, Januari 2014, hlm. 44-45

${ }^{18} \mathrm{Umi}$ Sumbulah, dkk, Pluralisme Agama: Makna dan Lokalitas Pola Kerukunan..., hlm. 4

${ }^{19}$ Mariyadi Faqih, "Menegakkan Hak Beragama di Tengah Pluralisme", Konstitusi, Volume 8, Nomor 4, Agustus 2011, hlm. 438
} 
eksklusif) justru masih cenderung memonopoli kebenaran agama (truth claim) dan klaim keselamatan (salvation claim). Padahal secara sosiologis, truth claim dan salvation claim itu, selain memunculkan berbagai konflik sosial politik, juga berdampak pada terjadinya beragam "perang" antar agama. ${ }^{20}$

Pada saat ini, perbedaan agama telah menjadi salah satu masalah besar yang patut untuk memperoleh perhatian serius. Sedemikian seriusnya masalah ini, sampai-sampai dapat menimbulkan perpecahan suatu bangsa, terjadinya konflik sosial hingga timbulnya perang sipil di antara warga negara. Perbedaan di antara suatu bangsa yang majemuk, di satu sisi dapat memperkaya keanekaragaman bangsa itu sendiri, tapi di lain pihak dapat juga menimbulkan suatu jurang pemisah di antara mereka. ${ }^{21}$

Hal lain yang berpotensi memicu konflik adalah terletak pada watak agama yang ekspansif. Khususnya agama samawi Islam dan Kristen yang sama-sama mengklaim sebagai agama misi dan dakwah. Proses penyebaran misi atau dakwah yang tidak memiliki rambu-rambu secara jelas, dapat menciptakan kecemasan dan kecemburuan kelompok agama lain dan pada gilirannya bisa melahirkan konflik. Hal ini adalah gesekan yang paling efektif untuk saling membenci dan menimbulkan fitnah antar umat beragama. ${ }^{22}$

Menurut Haedar Nashir dalam bukunya Agama dan Krisis Kemanusiaan Modern, dijelaskan bahwa secara garis besar ada lima faktor yang menyebabkan konflik umat beragama dalam masyarakat, yaitu: ${ }^{23}$

1. Stratifikasi Sosial Lapisan sosial dalam kehidupan masyarakat seperti perbedaan tingkat status sosial dan ekonomi antar pemeluk agama maupun para pemimpin, yang antara lain dapat melahirkan kecemburuan sosial. Stratifikasi ini merupakan faktor yang cukup kuat dapat mempengaruhi faktor-faktor lainnya, karena bersifat kompleks dan struktural.

2. Kepentingan ekonomi dan politik Kepentingan-kepentingan nyata setiap kelompok masyarakat termasuk para pemeluk agama dan para pemimpin setiap agama yang sama dalam memperebutkan sumber-sumber kehidupan ekonomi dan politik sebagai kebutuhan sosial yang penting dalam memperebutkan aset kekuasaan politik, seperti menjadi anggota DPR, Gubernur, Bupati dan lainnya. Kepentingan ini dipengaruhi oleh stratifikasi sosial dari masing-masing kelompok umat maupun para pemimpinnya.

3. Penafsiran agama Perbedaan penafsiran atau pemahaman agama yang antara lain melahirkan sikap fanatisme berlebihan terhadap mazhab atau paham agama secara

\footnotetext{
${ }^{20}$ Umi Sumbulah, dkk, Pluralisme Agama: Makna dan Lokalitas Pola Kerukunan..., hlm. 13

${ }^{21}$ Surya Adi Sahfutra, "Gagasan Pluralisme Agama Gus Dur Untuk Kesetaraan Dan Kerukunan", Religi, Vol. X, No. 1, Januari 2014 , hlm. 92-93

${ }^{22}$ Surya Adi Sahfutra, "Gagasan Pluralisme Agama Gus Dur"..., hlm. 93

${ }^{23}$ Surya Adi Sahfutra, "Gagasan Pluralisme Agama Gus Dur”..., hlm. 93-94
} 
berlebihan, baik inter maupun antar pemeluk agama yang berbeda, baik pada level umat awam maupun para pemimpinnya.

4. Mobilisasi kegiatan dakwah Usaha mempertahankan dan memperluas jumlah jama'ah yang menjadi pengikut paham maupun gerakan dakwah yang dilakukan oleh setiap kelompok agama di lingkungan agama yang sama maupun terhadap orang yang berbeda agama, termasuk dalam melakukan mobilitas sosial kelompok terutama para elit pemimpinnya.

5. Keyakinan agama Keyakinan terhadap kepercayaan yang mendasar dan dianggap mutlak yang menyangkut komitmen utama keberagamaan bersifat sakral dan fundamental bagi setiap pemeluk agama.

Pluralitas agama adalah fakta yang tak terbantahkan, siapapun suka atau tidak, mustahil hanya agamanya saja yang berhak hidup dan berkembang di bumi yang satu ini, di mana semua manusia hidup. Sikap anti atau merasa tidak senang atas kehadiran kepercayaan atau agama lain dengan segala implikasi pengalaman ajarannya adalah sikap yang menentang sunnatullah itu sendiri, sebuah ketetapan Tuhan atas keberagaman kepercayaan dan agama. ${ }^{24}$

Dari paparan diatas dapat kita lihat tantangan pluraisme agama yaitu banyaknya agama dan keyakinan yang dianut oleh masyarakat Indonesia tentu akan melahirkan gesekan-gesekan kecil bahkan gesekan besar. Bila kondisi ini dibiarkan tentu akan berdampak pada disintegrasi bangsa. Untuk itu perlunya pemahaman pluralisme agama yang tanpa adanya konflik antar umat beragama. Walaupun beda agama tidak lantas dibenci tapi harus di cintai dan disayangi.

\section{b. Peluang}

Pluralisme agama di Indonesia yaitu Adanya kesadaran untuk membangun ikatan kehidupan secara utuh dan bulat, tidak lain adalah berangkat dari kenyataan sekaligus pengalaman bangsa Indonesia dalam upayanya untuk mempertahankan sekaligus mencapai cita-cita proklamasi kemerdekaan yang terkandung dalam Konstitusi Negara Republik Indonesia. Ada masa kemajemukan (pluralitas) dari bangsa ini menjadi satu kekuatan yang menghantarkan sekaligus menjadikan keyakinan akan kemampuannya untuk berdiri sendiri (merdeka) berdiri sama tinggi dan duduk sejajar dengan bangsa-bangsa lainnya. ${ }^{25}$

Peluang pluralisme agama di Indonesia tidak menggunakan pendekatan pluralisme hitam putih dan salah benar, sehingga yang benar masuk surga dan yang salah masuk neraka, tetapi berupaya melihat apa yang menjadi esensi sesungguhnya ajaran suatu agama sembari berupaya menerapkannya dalam kehidupan sehari-hari untuk meraih kedamaian. Kemudian lebih jauh melihat secara perennial bahwa semuannya itu berawal dari satu sumber yang sama, yakni kebenaran mutlak. Bertolak dari pendekatan demikian, akan ditemukan benang merah yang menghubungkan semua agama yang benar bahwa

${ }^{24}$ Surya Adi Sahfutra, "Gagasan Pluralisme Agama Gus Dur”..., hlm. 96

${ }^{25}$ Firdaus Syam, "Dilema Pluralitas: Hambatan Atau Penguatan Demokrasi Bangsa Indonesia?", Ilmu Hukum, Vol. 14, No. 2, September 2011, hlm. 257 
sesungguhnya agama-agama samawi datang silih berganti memiliki subtansi mendasar, namun dengan format yang berbeda-beda. Dan sebagai Negara yang majemuk kita tidak boleh mengabaikan perbedaan format agama, tetapi harus menghormatinya. Kita menghormati dan meyakini agama yang kita peluk sepenuh dan setulus hati, namun tidak mengabaikan dan apalagi menghina agama orang lain. Dengan demikian akan terciptalah keharmonisan dan kedamaian sebagaimana yang dikehendaki oleh ajaran agama itu sendiri. ${ }^{26}$

Mukti Ali menawarkan, apa yang disebut dengan prinsip setuju dalam perbedaan (agree in disagreemenf). yang biasa diartikan setuju dalam perbedaan. Mengenai pengertian konsep ini, beliau menguraikan lebih lanjut sebagai berikut:

"Bangsa Indonesia yang kini sedang membangun menuju manusia seutuhnya dalam Plural Society masyarakat serba ganda, baik keyakinannya, agamanya, bahasa dan budayanya. Manusia Indonesia yang beragama ini dituntut supaya rukun dalam kehidupan agama. Kericuhan dalam kehidupan agama merupakan halangan bagi pembangunan. Pembangunan mustahil dilaksanakan dalam masyarakat yang kacau balau. Kerukunan hidup masyarakat merupakan pra-kondisi bagi pembangunan. Rukun dalam kehidupan agama dapat tercipta apabila tiap-tiap orang itu saling tenggang menenggangkan rasa dan lapang dada (toleran)."27

Gagasan ini menekankan bahwa pemeluk agama seharusnya menyadari bahwa agama yang ia peluk itulah agama yang paling baik. Walaupun demikian, ia mengakui di antara agama yang satu dengan agama-agama lainnya selain terdapat perbedaan-perbedaan juga terdapat persamaan-persamaan. Pengakuan seperti ini akan membawa kepada suatu pengertian yang baik yang dapat menimbulkan adanya saling harga menghargai dan saling hormat menghormati antara kelompok-kelompok pemeluk agama yang satu dengan kelompok-kelompok penganut agama yang lain. ${ }^{28}$

Setiap pemeluk agama hendaknya meyakini dan mempercayai kebenaran agama yang dipeluknya itu, sikap ini menurut Mukti Ali, adalah suatu sikap yang wajar dan logis. Keyakinan akan kebenaran terhadap agama yang dipeluknya ini tidak membuat dia bersikap eksklusif, akan tetapi justru mengakui adanya perbedaan-perbedaan agama yang dianut orang lain di samping tentu saja persamaan-persamaan dengan agama yang dipeluknya. sikap seperti ini akan membawa kepada terciptanya sikap "setuju dalam perbedaan" yang sangat diperlukan untuk membina dan mengembangkan paradigma toleransi dan kerukunan hidup antarumat beragama di Indonesia. ${ }^{29}$

${ }^{26}$ Yunasril Ali, Sufisme Dan Pluralisme: Memahami Hakikat Agama-Agama..., hlm. 37

${ }^{27}$ Toguan Rambe, "Pemikiran A. Mukti Ali Dan Kontribusinya Terhadap Kerukunan Antarumat Beragama”, Al-Lubb, Vol. 1, No. 1, 2016, hlm. 34

${ }^{28}$ Iskandar Zulkarnain, "Hubungan Antar komunitas.. . ,hlm. 696

${ }^{29}$ Iskandar Zulkarnain, "Hubungan Antar komunitas . . ., hlm. 697 
Di samping itu Peluang pluralisme agama di Indonesia bila dirawat dengan baik akan berdampak pada sehatnya hubungan antar umat beragama. Dengan demikian, Indonesia sebagai Negara majemuk akan menjadi Negara percontohan dalam merawat kerukunan.

\section{Kesimpulan}

Tantangan Indonesia Sebagai Negara Pluralisme Agama Yaitu Banyaknya Agama Dan Keyakinan Yang Dianut Oleh Masyarakat Indonesia Tentu Akan Melahirkan Gesekan-Gesekan Kecil Bahkan Gesekan Besar. Bila Kondisi Ini Dibiarkan Tentu Akan Berdampak Pada Disintegrasi Bangsa. Untuk Itu Perlunya Pemahaman Pluralisme Agama Yang Tanpa Adanya Konflik Antar Umat Beragama. Walaupun Beda Agama Tidak Lantas Dibenci Tapi Harus Di Cintai Dan Disayangi. Adapun peluang pluralisme agama bagi keutuhan bangsa yaitu bila dirawat dengan baik akan berdampak pada sehatnya hubungan antar umat beragama. Dengan demikian, Indonesia sebagai Negara majemuk akan menjadi Negara percontohan dalam merawat kerukunan.

\section{Daftar Pustaka}

Adi Sahfutra, Surya. "Gagasan Pluralisme Agama Gus Dur Untuk Kesetaraan Dan Kerukunan”, Religi, Vol. X, No. 1, Januari 2014

Ali, Yunasril. Sufisme Dan Pluralisme: Memahami Hakikat Agama-Agama Dan Relasi Agama-Agama, Jakarta: PT Alex Media Komputindo, 2012

Faqih, Maruyadi. "Menegakkan Hak Beragama di Tengah Pluralisme", Konstitusi, Volume 8, Nomor 4, Agustus 2011

Hanik, Umi. "Pluralisme Agama Di Indonesia”, Volume 25 Nomor. 1, Januari 2014

Khaerurrozikin, Ahmad. "Problem Sosiologis Pluralisme Agama Di Indonesia", KALIMAH, Vol. 13, No. 1, Maret 2015

Masykur, Said. "Pluralisme Dalam Konteks Studi Agama-Agama", Toleransi: Media Komunikasi Umat Beragama Vol. 8, No. 1, Januari - Juni 2016

Muchtar Ghazali, Adeng. "Pendidikan Islam dalam Dinamika Kehidupan Beragama di Indonesia", Intizar, Volume 23, No. 1, 2017

Pradipta, Yudwy, ddk. "Efektifitas Komunikasi Interpersonal Umat Beragama di Perumahan Bekasi Jaya Indah Rt 10/14", Studi Al-Quran, Volume. 10, No. 2, 2014

Rambe, Toguan. "Pemikiran A. Mukti Ali Dan Kontribusinya Terhadap Kerukunan Antarumat Beragama”, Al-Lubb, Vol. 1, No. 1, 2016

Rohman, Fathur. dkk, "Membangun Kerukunan Umat Beragama Dengan Nilai-Nilai Pluralisme Gus Dur", An-Nuha Vol. 5, No. 2, Desember 2018

Subkhan, Imam. Hiruk Pikuk Wacana Pluralisme di Yogya, Yogyakarta: Kanisius, 2007

Sumbulah, Umi dan Nurjanah. Pluralisme Agama: Makna dan Lokalitas Pola Kerukunan Antar umat Beragama, Malang: Maliki Press, 2013 
12 Pluralisme Agama di Indonesia ....

Suryana, Toto. "Konsep Aktualisasi Kerukunan Antar Umat Beragama”, Ta’lim, Vol. 9 No. 2 -2011

Syam, Firdaus. "Dilema Pluralitas: Hambatan Atau Penguatan Demokrasi Bangsa Indonesia?”, Ilmu Hukum, Vol. 14, No. 2, September 2011

Utoyo, Marsudi. "Wewenang Dan Tugas Pemerintah Dalam Perkembangan Paham Pluralisme Agama”, Lex Librum, Vol. II, No. 1, Desenfier 2015

Widiat Moko, Catur. "Pluralisme Agama Menurut Nurcholis Madjid 1939-2005 Dalam Konteks Keindonesiaan”, Medina-Te, Vol.16, No.1, Juni 2017

Zulkarnain, Iskandar. "Hubungan Antar komunitas Agama Di Indonesia : Masalah Dan Penanganannya", Vol 16 No.4 Desember 2011 